\title{
KEBIJAKAN IDEOSINKRETIK (WHOLISTIC) JOKO WIDODO (JOKOWI) DALAM KONPERENSI ASIA AFRIKA TAHUN 2015
}

Laode Muhamad Fathun

\begin{abstract}
Abstrak
Paper ini akan mennganalisis transformasi kebijakan luar negeri Indonesia dari masa ke masa. Transformasi itu terlihat ketika pergantian kepemimpinan di Indonesia. Perubahan kebijakan politik luar negeri Indonesia terjadi sesuai dengan tujuan dan situasi dalam kondisi kebutuhan internal dan eksternal. Sejak Soekarno memimpin Indonesia sampai era Jokowi menunjukan transformasi kebijakan politik luar negeri Indonesia. Jokowi yang menjadi presiden sejak 2014 membuat orientasi kebijakan luar negeri Indonesia pada pengelolaan asset maritime sebagai tujuan pembangunan Indonesia. Hal tersebut dilakukan melalui internasionalisasi kebijakan poros maritim dalam berbagai konferensi internasional. Salah satu yang menjadi model analisi wholistic Jokowi adalah ketika orientasi tersebut di internasionalisasi dalam Konperensi Asia Afrika Di Indonesia. Dengan bekal sebagai tuan rumah Indonesia semakin leluasa menyebarkan visi tersebut dalam marketing politik. Tujuannya adalah agar setiap peserta konferensi mengetahui dan terpengaruh bahwa Indonesia sebagai negara maritim dan sudah fokus mengelola aset maritim. Sehingga, diperlukan kerjsamaa internasional baik tingkat nasional, regional dan global.
\end{abstract}

Kata kunci: transformasi, kebijakan luar negeri, Jokowi, Maritim, konperensi Asia Afrika 


\section{Dinamika Global | Volume 02 | No.02 | Desember 2017}

Pendahuluan

Sejak dulu Indonesia dalam kepemimpinan Soekarno memiliki peran penting di dunia Internasiona. Jelas sudah keadaan ini tidak bisa terbantahkan. Mulai dari menjadi inisiator lahirnya gerakan Non-Blok, pemerkasa berdirinya ASEAN dan munculnya pula organisasi tandingan ketika perang blok setelah perang dunia pertama yakni lahirnya organisasi persatuan Negara -negara Asia dan Afrika yang saat itu merupakan Negara-negara yang baru merdeka dari kolonialisme dan imprealisme barat.

Dalam model prinsip kebijakan luar negeri yang di keluarkan oleh Soekarno yakni "bebas aktif". Secara konvensional bebas di artikan bahwa Indonesia tidak memihak pada satu blok manapun baik barat maupun timur. Sedangkan aktif berkaitan dengan cita-cita UUD 195 seperti aktif menjaga ketertiban dunia. Namun, yang perlu di redefinisi adalah masalah konsep "bebas" itu apakah masih kontekstual atau tidak. Seperti yang sudah dijelaskan sebelumnyaa bahwa obejak kebijakan luar negeri sangat abstrak dan kondisional. Artinya bebas disini bukan lagi berarti tidak berpihak pada blok ideologi tertentu, tetapi memiliki restorasi makna misalnya bebas dalam arti menjalin kerjasama dengan Negara manapun demi atas nama kepentingan Negara atau million friends zero enemy dalam definisi semasa pemerintahan SBY.

Namun, konsep SBY tersebut sebernya masih harus di pertahankan dengan asumsi bahwa dalam usaha menjaga 


\section{Dinamika Global | Volume 02 | No.02 | Desember 2017}

ketertiban dunia Indonesia wajib menjalin hubungan internasional dengan Negara mana pun dengan tanpa intervensi. Kalau merujuk pada masa lalu arah kebijakan RI semasa Soekarno lebih di arahkan pada mencari dukungan internasional dengan status sebagai Negara baru merdeka. Kemudian bergeser pada masa Soeharto yang lebih mencitrakan pada proses pembangunan ekonomi secara besarbesaran. Setelah Soeharto jatuh tampuh kepemimpinan di lanjutkan oleh Habibie, dimana kebijakan Indonesia lebih di arahkan pada membentuk citra politik dengan munculnya kasus HAM semasa Soeharto, lepasnya Timor-Timur. Kemudian setelah itu Abdurahman Wahid menjadi Presiden selanjutnya dengan konsep pluralisme serta membentuk citra bahwa Indonesia adalah negara yang demokratis, plural.

Setelah Megawati menjadi Presiden disinilah menjadi pola lanjutan dari Soekarno sebab kerjasama yang terbentuk dimasa ini lebih condong pada Rusia sama dengan ketika Soekarno memimpin. Namun setelah SBY lengser bagaimanakah arah kebijakan RI selanjutnya, mengingat bahwa Indonesia memiliki peran penting dalam politik Internasional, terlibat dalam beberapa organisasi internasional, menjadi salah satu pengirim pasukan perdamaian, serta yang paling sering adalah menjadi tuan rumah konferensi internasional yang tentunya ini menjadi citra positif bagi Indonesia serta apakah ini menjadi agenda Jokowi selanjutnya.

Dalam konsep kebijakan luaar negeri Jokowi yang saat itu menjadi agenda debat Capres dan Cawapres lebih di 


\section{Dinamika Global | Volume 02 | No.02 | Desember 2017}

arahkaan pada unsur (1) Membangun identitas budaya maritim dengan mengedepankan praktek diplomasi dan kerjasama antar negara, (2) meningkatkan peran global berbasis pada diplomasi middle power, (3) memperluas keterlibatan kerjasama di kawasan Indo-Pasifik, (4) mempertajam diplomasi publik (G to $\mathrm{G}, \mathrm{G}$ to $\mathrm{B}, \mathrm{G}$ to $\mathrm{C}$. $\mathrm{P}$ to $\mathrm{P}$ ). Bebraapa pilar tersebut penuliss mengambil kesimpulan bahwa konsep kebijakan luar negeri Jokowi masih bersifat million friends zero enemy artinya Jokowi masih mengutamakan kerjasama melalui peran diplomasi untuk memperluas jangkauan kerjasama sehingga menginginkan peran dalam dunia internasional yang lebih aktif. Namun, keunikannya adalah Jokowi menyusun agenda kekuatan Indonesia yang lama hilang yakni Negara berbasis maritim atau blue power. Hal ini, sudah lama di tinggalkan oleh sejumlah presiden Indonesia Soekarno pernah berucap dalam konsep geopolitiknya "bahwa Negara yang kuat adalah negara bahari (maritim).

Tentunya dengan model baru ini mengembalikan kembali citra Indonesia sebagai Negara yang memiliki akses laut yang besar dan memiliki potensi sebagai basis ekonomi, militer, budaya yang akan menjadi bagian agenda pembangunan nasional. Upaya melancarkan cita-cita tersebut sesuai arah kebijakan luar negerinya Jokowi mempromosikannya dalam beberapa forum internasional seperti KTT APEC, pertemuan Negara-negara ASEAN di Myanmar dll beberapa konfernsi lainya tidak terkecuali dengan konperensi Asia Afrika tahun 2015. 


\section{Dinamika Global | Volume 02 | No.02 | Desember 2017}

Pembahasan

Konperensi Asia Afrika di awali pada 28 april-02 Mei 1954 yakni konferensi kolombo atau konferensi lima negara pertama. Kolombo merupakan ibu kota dari Srilangka, dimana lima Negara tersebut adalah Perdana Menteri Pakistan: Muhammad Ali Jinnah; Perdana Menteri Sri Lanka: Sir John Kotelawala; Perdana Menteri Burma (Myanmar): U Nu; Perdana Menteri Indonesia: Ali Sastroamijoyo; Perdana Menteri India: Jawaharlal Nehru. Konferensi tersebut agenda pembahasan pada melihat bagaimana kesiapan Vietnam untuk mengikuti konferensi di Jenewa. Selain itu pula kelima Negara membahas keinginan untuk membuat konferensi yang melibatkan sejumlaah Negara yang ada di Asia dan Afrika dan mereka menyepakati Indonesia sebagai tuan rumah konperensi Asia Afrika. Menindaklanjuti hasil konferensi sebelumnya maka tanggal 22-29 desember di tahun 1954 dengan peserta yang sama dilaksanakan konferensi di Bogor dengan tujuan untuk menetapkan bahwa konperensi Asia Afrika akan dilaksanakan pada 18-24 April 1955, mendukung Indonesia untuk pembebasan Irian Barat serta menetapkan tujuan dilaksanakannya konperensi.

Pada tanggal 18-24 April 1955 dilaksanakanlah konperensi Asia Afrika pertama di Kota Bandung dengan menghadirkan 29 negara anggota peserta dengan komposisi panca Negara yakni Indonesia, Pakistan, Srilanka, India, dan Myanmar menjadi Negara yang mengundang sejumlah utusan wakil lainya seperti 6 negara Afrika dan 18 negara meliputi Asia 


\section{Dinamika Global | Volume 02 | No.02 | Desember 2017}

(Thailand, Filipina, Kampuchea, Vietnam Selatan, Nepal, RRC, Laos, Jepang, Vietnam Utara, Irak, Saudi Arabia, Syria (Suriah), Turki, Yaman), Yordania, Lebanon, Afghanistan, Iran, dan Afrika (Mesir, Liberia, Libia, Sudan, Pantai Emas/Gold Coast, Etiopia). Seperti yang telah dideskripsikan di atas bahwa Negara-negara Asia dan Afrika ini ingin melakukan sumbangsih perdamian internasional. Namun, dari analisis bisa dihipotesakan bahwa tentunya negara-negara tersebut melakukan sebuah integrasi.

Michael Sullilvan mengatakan bahwa ada beberapa asumsi ketika beberapa Negara melakukan integrasi dalam sebuah organisasi yakni, (a) bahwa terjadinya konflik antar manusia karena tidak adanya kesadaran pada identitas yang sama atau bisa dikatakan saling memahami, dan tidak adanya kesamaan dalam ilmu humaniora disebutkan (common sensitivity), (b) dalam konflik tertentu tidak adanya cross pressure artinya kelompok penekan untuk menengahi konflik dan tidak saling berhadapan langsung, (c) dalam system yang anarki diperlukan sebuah system atau subsitem sebagai pengelola, (d) dalam pandang neofungsionalis bahwa kerjasama sama yang terbentuk sangat non ideologis dan non sentral. Sedangkan intergrasi itu sendiri di artikan sebagai sebuah penyatuan rasa baik ekonomi, politik, sosial atau istilah Karl Deucth "security community" (Mas'oed, 1994, 151-153).

Lebih lanjut dijelaskan oleh Louis Cantori intergrasi mengacu pada sebuah sistem ordinat dimana dilakukan oleh beberapa Negara dengan asumsi keterikatan etnis, sejarah, 


\section{Dinamika Global | Volume 02 | No.02 | Desember 2017}

sosial, geografi, budaya untuk membentuk sebuah identitas baru dalam sebuah sistem. Artinya integrase mengacu pada kekuasaan supranasional dimana para elit politik saling berusaha untuk memberikan loyalitas pada system yang telah terintegrasi (May Rudi, 2003: 84-85). Adanya kesadaran tersebutlah seperti kedekatan geografis, kemiripan budaya, entitas agama, kesejarahan akibat kolonialisme, serta terjadinya pemisahan kekuatan barat dan timur sehingga konferensi ini bisa terbentuk dengan harapan untuk memajukan kesejateraan umum ekonomi, politik, sosial, menghindarkan diskriminasi sosial rasisme dan etnisme, serta berupaya melihat peran Negara-negara tersebut dalam perdamaian dunia, menghapuskan kolonialisme, serta lebih meningkatkan kerjasama aktif semua Negara seperti mendukung pelucutan senjata antar pihak yang berkonflik, penghentian pengembangan senjata nuklir yang tentunya untuk masyarakat internasional yang aman dan damai. Jackson menjelaskan bahwa pada dasarnya hubungan antar Negara yang terbentuk di upayakan untuk menjamin 5 dasar hubungan internasional yakni keamanan, kebebasan, ketertiban, keadilan dan kesejateraan (2005:4), Jackson (2014:6 Revisi Edisi kelima).

Menyadari pentingnya konferensi tersebut sebagai salah satu penengah antara blok barat dan timur maka ada beberapa hasil konferensi yakni (1) menghormati hak-hak dasar manusia, tujuan, serta asas yang termuat dalam Piagam PBB;

(2) menghormati kedaulatan dan integritas teritorial semua 


\section{Dinamika Global | Volume 02 | No.02 | Desember 2017}

bangsa; (3) mengakui persamaan ras dan persamaan semua bangsa, baik bangsa besar maupun bangsa kecil; (4) melakukan intervensi atau ikut campur tangan dalam persoalan dalam negeri negara lain; (5) menghormati hak-hak tiap bangsa untuk mempertahankan diri, baik secara sendirian maupun secara kolektif sesuai dengan Piagam PBB; (6) a) tidak menggunakan peraturan-peraturan dari pertahanan kolektif untuk bertindak bagi kepentingan khusus salah satu negara besar; b) tidak melakukan tekanan terhadap negara lain; (7) tidak melakukan tindakan atau ancaman agresi ataupun penggunaan kekerasan terhadap integritas teritorial atas kemerdekaan politik suatu negara; (8) menyelesaikan segala perselisihan internasional secara damai sesuai dengan Piagam PBB; (9) memajukan kepentingan bersama dan kerja sama internasional; (10) menghormati hukum dan kewajiban internasional lainnya. Konferensi tersebut dikenal dengan sepuluh dasasila bandung atau bandung declaration. "Let a new Asia and a new Afrika be born" bunyi pidato Bung Karno tahun 1955. Setelah tahun 1955 Konferensi pertemuan kedua kembali dilaksanakan di Bandung dan Jakarta pada tanggal 18-24 April 2005 memperingati 50 tahun lahirnya konperensi Asia Afrika yang dihadiri langsung oleh Sekejen PBB asal Afrika Selatan yakni Kofi Annan dengan mengambil tema menghasilkan NAASP (New Asian-African Strategic Partnership). Pada hakekatnya kerjasam yang terbentuk masih sama cuman pergeseranya adalah makna hilangnya keterlibatan rivalitas 


\section{Dinamika Global | Volume 02 | No.02 | Desember 2017}

blok barat dan timur tetapi substansi kerjasama masih lanjutan sebelumnya.

Analisis

a. Arah kebijakan Politik Luar negeri Indonesia dalam Konperensi Asia Afrika 2015

Dalam Undang-undang RI No.37 Tahun 1999 bahwa kebijakan luar negeri Indonesia merupakan seprangkat nilai, cita-cita, prinsip, dan kepentingan Indonesia yang ditempuh melalui jalan diplomasi. Walaupun dalam upaya merebut kepentingan nasional setiap Negara memiliki cara lain melalui perang demikian pula tercantum dalam Undang-undang bahwa President berhak menyatakan perang jika kepentingan Indonesia tergangu. Arah kebijakan luar negeri Indonesia yang ditempuh melalui diplomasi berarti politik luar negeri Indonesia dalam konperensi Asia Afrika berbentuk analisis level kualisi. Artinya dalam kualisi tersebut Indonesia masuk dalam sebuah system internasional dengan sejumlah aktor yang sama dengan kesamaan tujuan yang sama berarti bisa dikatakan pendekatan melihat pentingnya sitem internasional atau dunia Internasional dalam mempengaruhi kebijakan politik luar negeri.

Sejalan dengan itu Ricard W menjelaskan bahwa merupakan konversi input berupa infromasi tentang apa yang harus dilakukan sebuah Negara menjadi output berupa diplomasi atau aliansi/ kualisi (2012:411). Begitu juga 


\section{Dinamika Global | Volume 02 | No.02 | Desember 2017}

Coloumbis dan Wolfe mengatakan bahwa kriteria kebijakan luar negeri Negara mengarah pada netralis, non blok, intervensionis, imprealis, ofensif, difensif, internasionalis, status quo, bebas aktif aliansi (1999:127). Artinya sifat poltik luar negeri Negara-negara Asia Afrika pada saat itu menganut prinsip bebas aktif (non blok) sehingga membentuk aliansi termasuk Indonesia. Apapun yang dilakukan pemerintah berupa tindakan, sikap, komitmen, prinsip tujuan adalah reformulasi dari kepentingan masyarakat yang diwakili oleh pemerintah (Carlesnaes:2013; 689).

Konperensi Asia Afrika yang dilaksanakan di Bandung dan Jakarta pada tanggal 19 sampai 23 april 2015 sekaligus memperingati 60 tahun kerjasama konperensi Asia Afrika. Konferensi tersebut mengundang 109 perwakilan Negara dan 25 organisasi internasional, dengan teman meningkatkan kerjasama selatan-selatan untuk menciptakan kesejateraan dan pedamaian. Dalam agenda tersebut di susun dengan tanggal 19 menggelar pertemuan para pejabat tinggi setingkat direktuk jendral, di esok harinya tanggal 20 dilaksanakan pertemuan tingkat mentri atau KTM (Konferensi Tingkat Menteri), pada tanggal 21 dilaksanakan pertemuan para pengusaha untuk penguatan kerjasama ekonomi Asia Afrika, dimana ada sekitar 500 pengusaha akan berpartisipasi dalam konferensi tersebut. Sedangkan tanggal 22-23 barulah dilaksanakan diplomasi tingkat tinggi atau konferensi tingkat kepala negara/ pemerintahan (summit diplomacy) yang disaksikan oleh 34 negara dan 86 negara perwakilan. Acara 


\section{Dinamika Global | Volume 02 | No.02 | Desember 2017}

puncak akan dilaksanakan di Bandung dimana menjadi tempat awal dilaksanakannya konperensi Asia Afrika.

Konferensi tingkat pejabat tinggi dengan agenda menjadi bahasan adalah (a) menelaah kembali dasasila bandung yang sudah dituliskan sebelumnya, (b) meningkatkan kembali kerjasama strategis Negara-negara Asia Afrika, serta (c) mendukung deklarasi kemerdekaan Palestina. Pada poin (b) memiliki tiga pilar utama yakni (1) menyangkut komitmen politik untuk mendukung palestina menjadi Negara, reformasi $\mathrm{PBB}$, perdamaian internasional serta penguatan kerjasama regional kawasan, (2) pada pilar ini menjadi perbedaan arah kebijakan luar negeri Jokowi yakni penguatan kerjasama maritim, dimana Jokowi menginginkan untuk menjadi poros maritm dunia (blue economic power), mengintenskan konektivitas serta mobilisasi bisnis, dan (3) berhubungan dengan sosial budaya, seperti gender, diplomasi bencana, migrasi, pemuda. Pada pertemuan tersebut juga terjadi Reinvigorating the New Asian-African Strategic Partnership (NAASP) yang ditetapkan pada tahun 2005. Kerjasama utamanya dengan delapan fokus NAASP seperti terorisme, organisasi kejahatan transnasional, keamanan pangan, keamanan energi, kerjasama universitas.

b. Variabel Ideosinkretik Jokowi dalam Kebijakan Politik Luar negeri Indonesia (Wholistic)

Setelah Jokowi dan JK resmi dilantik menjadi Presiden dan Wakil President Indonesia pada tahun 2014 yang lalu tentunya setiap president memiliki presepsi dan mimpi untuk 


\section{Dinamika Global | Volume 02 | No.02 | Desember 2017}

mensejaterahkan rakyatnya sebagai jawaban atas janji-janji politik yang disampaikan semasa kampanye. Di atas telah di deskripsikan bahwa Jokowi ingin membawa arah baru kebijakan luar negeri Indonesia yang merupakan konseptual dari Soekarno yakni sebagai Negara bahari. Namun perbedaannya adalah kondisional dan situasional sangat berpengaruh dalam menjalankan kebijakan luar negeri. Alex Mint menjelaskan:

Foreign policy choices range from the dramatic to leaders make decisions to go to war, make peace, form an alliance, establish diplomatic relations, implement a position on nuclear nonproliferation, impose economic sanctions, or ratify global environmental agreements. The level of analysis in foreign policy decision making (the individual, group, coalition). foreign policy decisions (the decision environment, psychological factors, international factors, and domestic influences) Alex Mintz:20103-4). Decisions can be made based on holistic, heuristic, or wholistic search (Sage 1990, 239-242). Holistic search involves a thorough examination of all the alternatives, dimensions, and implications of the decision. Heuristic decisions are made while employing cognitive shortcuts. Wholistic decisions are made while disregarding the components of the decision. Such decisions are intuitive, involving standard operating procedures (SOPs) and/or the use of analogies (ibid.). Heuristic and wholistic searches are more process oriented than holistic searches (Alex Mintz Ibid:17).

Kebijakan maritim sudah lama fakum pula semasa SBY hanya sebatas retorika politik dan tanpa realisasi. Pada masa Jokowi inilah mencoba memainkan peran diplomasi maritim dalam berbagai konferensi salah satunya di konperensi Asia Afrika. Analisis kebijakan luar negeri dalam variabel wholistic atau ideosinkretik menitik beratkan pada Individu sebagai pengambil keputusan. Rosenau menjelaskan vaariabel 


\section{Dinamika Global | Volume 02 | No.02 | Desember 2017}

ideosinkretik berkaitan dengan presepsi, karakteristik pribadi, image yang terdiri atas ketenangan vs ketergesagesahan, kemarahan vs prudensi, pragmatism vs ideology, keunggulan vs keterbelakangan, kreativitas vs kehancuran, ketakutan dan percya diri berlebihan, psikologis, pendidikan, latar belakang orang tua masa lalu, kegagalan, persahabatan, kondisi keuangan, merupakan sejumlah factor yang bisa saja mempengaruhi kebijakan seorang pemimpin (1971: 95).

McClelland menyambungkan ketika pengmabilan keputusan di ambil secara individual maka keputusan tersebut melalui proses itelektual, kognitisme dimana individu mengeneralisasi sebagai aktor rasional dari semua kepentingan masyarakat sehingga, seperti melakukan game theory (1999:168). Hal ini bisa disamakan dalam konteks teori menajemen yakni teori A yang asumsinya tanggung jawab penuh pada individu, tegas pengendalian formal, promosi dan evaluasi cepat (Uci Yuliati, 2006:177). Untuk melihat fenomena wholistik oleh Jokowi bisa dilihat tabel di bawah:

Tabel 1 Biodata Joko Widodo

\begin{tabular}{|l|l|}
\hline Nama Lengkap & Ir. Joko Widodo \\
\hline $\begin{array}{l}\text { Tempat, Tanggal } \\
\text { Lahir }\end{array}$ & Surakarta, 21 Juni 1961 \\
\hline Alamat & $\begin{array}{l}\text { Jl. Taman Suropati No. 7, Rt. 05/05. Menteng, Jakarta } \\
\text { Pusat }\end{array}$ \\
\hline Agama & Islam \\
\hline $\begin{array}{l}\text { Riwayat } \\
\text { Pendidikan }\end{array}$ & $\begin{array}{l}\text { a. SDN III Tirtoyoso, Solo } \\
\text { b. SMPN 1 Solo }\end{array}$ \\
& $\begin{array}{l}\text { c. SMAN 6 Solo } \\
\text { d. Fakultas Kehutanan Universitas Gadjah Mada } \\
\end{array}$ \\
\hline
\end{tabular}




\begin{tabular}{|c|c|}
\hline $\begin{array}{l}\text { Pengalaman } \\
\text { Pekerjaan }\end{array}$ & $\begin{array}{ll}\text { a. } & \text { Eksportir Mebel } \\
\text { b. Walikota Surakarta (2005-2010 dan 2010-2012) } \\
\text { c. Gubernur Prov. DKI Jakarta (2012-2014) } \\
\text { d. Presiden Republik Indonesia (2014-sekarang) }\end{array}$ \\
\hline $\begin{array}{l}\text { Pengalaman } \\
\text { Organisasi }\end{array}$ & $\begin{array}{l}\text { a. Ketua Bidang Pertambangan dan Energi KADIN } \\
\text { Surakarta (1992-1996) } \\
\text { b. Ketua ASMINDO Komda Surakarta (2002-2007) } \\
\text { c. Anggota Partai Demokrasi Indonesia Perjuangan } \\
\text { (PDI-P) }\end{array}$ \\
\hline Nama Ibu & Sujiatmi \\
\hline Nama Ayah & Alm. Noto Mihardjo \\
\hline Nama Saudara & $\begin{array}{ll}\text { 1. } & \text { Iit Sriyantini } \\
\text { 2. } & \text { Ida Yati } \\
\text { 3. } & \text { Titik Relawati }\end{array}$ \\
\hline Nama Istri & Hj. Iriana, S.E., M.M. \\
\hline Nama Anak & $\begin{array}{ll}\text { 1. } & \text { Gibran Rakabuming Raka } \\
\text { 2. Kahiyang Ayu } \\
\text { 3. Kaesang Pangarep }\end{array}$ \\
\hline
\end{tabular}

Sumber: Data Komisi Pemilihan Umum Indonesia

Berikut visi -misi Jokowi dalam Pemilihan Presiden 2014

a. Mewujudkan keamanan nasional yang mampu menjaga kedaulatan wilayah, menopang kemandirian ekonomi dengan mengamankan sumberdaya maritim, dan mencerminkan kepribadian Indonesia sebagai negara kepulauan.

b. Mewujudkan masyarakat maju, berkeseimbangan dan demokratis berlandaskan Negara hukum.

c. Mewujudkan politik luar negeri bebas-aktif dan memperkuat jati diri sebagai negara maritim.

d. Mewujudkan kualitas hidup manusia Indonesia yang tinggi, maju dan sejahtera. 


\section{Dinamika Global | Volume 02 | No.02 | Desember 2017}

e. Mewujudkan bangsa yang berdaya-saing. Mewujudkan Indonesia menjadi negara maritim yang mandiri, maju, kuat, dan berbasiskan kepentingan nasional

f. Mewujudkan masyarakat yang berkepribadian dalam kebudayaan.

Sumber : Data KPU Mei Misi Jokowi -JK 2014 hlm.6

Data tersebut memperlihatkan bahwa misi Jokowi dalam kepemimpinannya adalah kembali melihat Indonesia dari sudut pandang geopolitik maritim. Teori geopolitik seperti Ratzel, Ritter yang menekankan pendekatan ruang hidup Negara (organism determinist, living space) yang berorientasi kontinental, Alfred Thayer Mahan merupakan pelopor orientasi maritim merupakan sejumlah menekankan bahwa kekuatan laut merupakan kekuatan dominasi Negara untuk menguasai dunia sea power maritime dan Sir Harold Mackinder dengan konsep The Heartland Theory merupakan sejumlah pemikir yang mungkin menjadi inspirasi pemerintahan Jokowi-JK.

Dari agenda misi Jokowi tersebut tiga di antaranya melihat pentingnya laut sebagai sumber kepentingan nasional Indonesia yang telah lama fakum. Dimana Jokowi memiliki visioner membangun kekuaatan nasional berbasir blue economi power. Jokowi melihat ada 3 masalh pokok bangsa Indonesia yang perlu dibenahi yakni (a) ancaman kewibaan bangsa, hal ini berkaitan dengan lemahnya penegaakan hukum, HAM, mengatasi konflik social dll (b) lemahnya sendi perekonomiaan bangsa. Jokowi melihat bahwa ekploitasi dan ekplorasi sumberdaya alam yang kurang maksimal termasuk 


\section{Dinamika Global | Volume 02 | No.02 | Desember 2017}

maritim menjadikan Indonesia belum bisa berdiri di atas kaki sendiri, (c) intoleransi dan krisis kepribadian bangsa. Jokowi melihat kembali perlunya membangun jati diri bangsa, nasionalisme, sikap solidaritas, gotong royong sebagai masalah yang harus di benahi secara komprehensif.

Tentunya dari aspek ideosinkretik, penulis melihat bahwa visi menjadi Negara berbasis maritim merupakan poin utama dan pembeda dan ciri arah kebijakan luar negeri Jokowi. Analisis selanjutnya jelas melihat dari segi pendidikan yang pengalaman hidup sebagai seorang pengusaha mebel di Solo. Dalam teori psikologis sangat jelas pengalaman seseorang agen bisa mempengaruhi apa yang menjadi keputusan. Hal ini terbukti dengan pernyataan Jokowi yang ingin menjadikan para diplomat dan perwakilan RI di berbagai negara dan kawasan untuk bukan sekedar profesi high-class tetapi Jokowi menginginkan mereka sebagai seorang sales yang berbasis marketing politik dan ada kecenderungan bahwa Jokowi memainkan simulasi game sebagai seorang manajer perusahaan yang bertitik tolak pada ekonomi.

Dan bahkan kontroversialnya adalah mengizinkan sejumlah BUMN untuk di pimpin oleh pengusaha asing agar untuk kemajuan bangsa. Simulasi ini bisa di bilang sangat keliru karena ketika membiarkan aset dalam negeri dikendalikan oleh asing itu tandanya memberikan soft sovereign kepada Negara lain. Yang baiknya adalah Jokowi mengambil dan meniru gaya menajeman kepemimpinan asing dan menejerial dan melakukan sejumlah manufer politik. 


\section{Dinamika Global | Volume 02 | No.02 | Desember 2017}

Penulis sangat optimis dikarenakan beberapa Universitas di Indonesia sudah sangat siap memegang amanat untuk mengembangkan negara. Namun, apakah keseriusan pemerintah yang masih bersifat "politik adalah imbalan" inilah yang menjadi masalah.

Dalam prakteknya di Konperensi Asia Afrika pun ini sangat jelas daan terlihat dari sejumlah pidato politik yang dikemukan baik oleh mentri luar negeri dan Jokowi sendiri. Meminjam istilah dari Jervis mengatakan bahwa dalam pidato politik setiap kepala Negara atau wakil negaara tertetuntu terkadang terjadi kesalahan prespsi oleh aktor lainya. Hal ini pun terjadi ketika Jokowi berpidato tentang keterlibatan IMF, Bank Dunia, WTO sebagai sejumlah organisasi yang menjadikan interdepedensi dan ketidak merataan pendapatan nasional bahkan kemiskinan di berbagai negara terutama Asia dan Afrika. Prespektif Ekonomi Politik Internasional ini sangat jelas menjadi kritikan oleh kaum Marxisme. Pidato saat itu ternilai sangat ekstrim mengingat sejumlah Negara masih tergantung pada organisasi tersebut termassuk Indonesia.

Namun, menteri luar negeri mencoba meluruskan maksud dari Jokowi adalah agar sejumlah organisasi dunia lebih adil dalam melakukan pinjaman dan membuat sejumlah regulasi internasional yang tidak terlalu mengikat dan membebani masyarakat internasional yang ada di kawasan terutama Asia dan Afrika. Berkaitan dengan itu tentunya keprihatinan Indonesia sebagai negara yang masuk G20 dan beberapa Negara Afrika memerlukan peran dominan Indonesia 


\section{Dinamika Global | Volume 02 | No.02 | Desember 2017}

sebagai mitra strategis untuk mengatasi sejumlah masalah dunia. Bukan tanpa bukti terjadwalkan sebelum konperensi Asia Afrika dimulai ada sekitar 19 kepala negara yang ingin berbicara langsung dengan Jokowi terutama sejumlah Negara Afrika yang masih dilanda berbagai masalah kemiskinan dan bencana penyakit ebola.

Jelas pernyatan Jokowi tersebut dalam prespektif neoklasik liberal Adam Smith tentang “invisible hands”, dimana ketika orang semakin kaya maka ada tangan-tangan mulianya untuk membantu orang lain. Namun, jelas sekali prespektif ini dibantah oleh kaum marxisme yang jelas depedennsi, neoliberalisasi akan menjadikan jurang pemisah lebih jauh antara si kaya daan si miskin. Konsep inilah yang dilihat oleh Jokowi bahwa terjadi kolonialisme baaru dalam politik internasional melalui sejumlah aturan neoliberal.

Mengutip May Rudy, physical security yang berkaitan dengan fisik seperti militer, Rules and Institution berkaitan dengan normatisme dalam hubungan inetrnasional, dan property berkaitan dengan barang dan jasa, sumber modal, system keuangan (2003:64). Sedangkan dalam konsep pidato Jokowi terlihat mengancam keamanan dari segi rules dan property. Artinya asumsi neoliberal adalah privatisasi, swastanisasi dan deregulasi. Konsep ini yang dilihat oleh Jokowi untuk ditinjau kembali oleh global governance. Dengan memainkan marketing politik oleh isu tersebut keuntungan dari pihak Indonesia karena hal ini sangat mengena terutama sejumlah negara Afrika. 


\section{Dinamika Global | Volume 02 | No.02 | Desember 2017}

Dengan memainkan pengatar dependensia, setelah itu pidato berlajut pada pernyataan dari mentri luar negeri Retno L.P. Marsudi Konperensi Asia Afrika adalah kemitraan strategis baru Asia-Afrika (New Asia-Africa Strategic Partnership), yang akan terealisasi melalui kerjasama maritim yang diinisiasi Indonesia. Maksudnya sudah jelas misi Indonesia adalah menggalang dukungan dan bantuan negara-negara Asia dan Afrika untuk mewujudkan Indonesia sebagai negara poros maritim serta negara berbasis ekonomi laut. Mengingat bahwa marketing politik maritim Jokowi sudah di sampaikan di KTT APEC dan ASEAN dengan dukungan negara Afrika ada kecendrungan visi Indonesia untuk akan terlaksana. Hal ini sangat jelas bahwa di Asia dan Afrika negara berbasis maritim seperti China, Jepang, India, Afrika Selatan, Korea, merupakan sejumlah negara besar yang meiliki dana investasi yang cukup besar untuk di masukan ke Indonesia.

Bukan hanya itu sejumlah Negara tersebut memiliki sejarah masalalu sebagai basis maritim dan menajemen maritim ketika masih berbentuk kerajaan begitu juga dengan Indonesia. Mempertegas pernyataan penulis mengutip esensi dalam pidato penutup yang disampaikan Jokowi di Bandung tanggal 24 april 2015 bahwa Jokowi sangat mengapresiasi antusiasme peserta konferensi dan mengharapakan kerjasama di antara peserta lebih intens dan ditingkatkan bahwa kerjasama mitra strategis dalam bidang maritim sangat potensial untuk memajukan kemajuan bangsa negara-negara 


\section{Dinamika Global | Volume 02 | No.02 | Desember 2017}

Asia Afrika. Meminjam istilah skema teori liberal dalam skema sebagai berikut:

Skema 1 Model Menuju Negara Modern

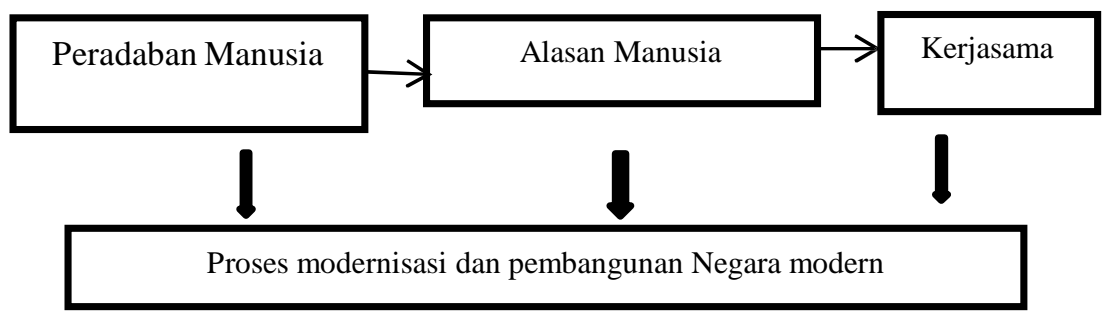

Sumber: (Jackson, 2014:178)

Skema 2 Analisis Ideosinkretik Holsti

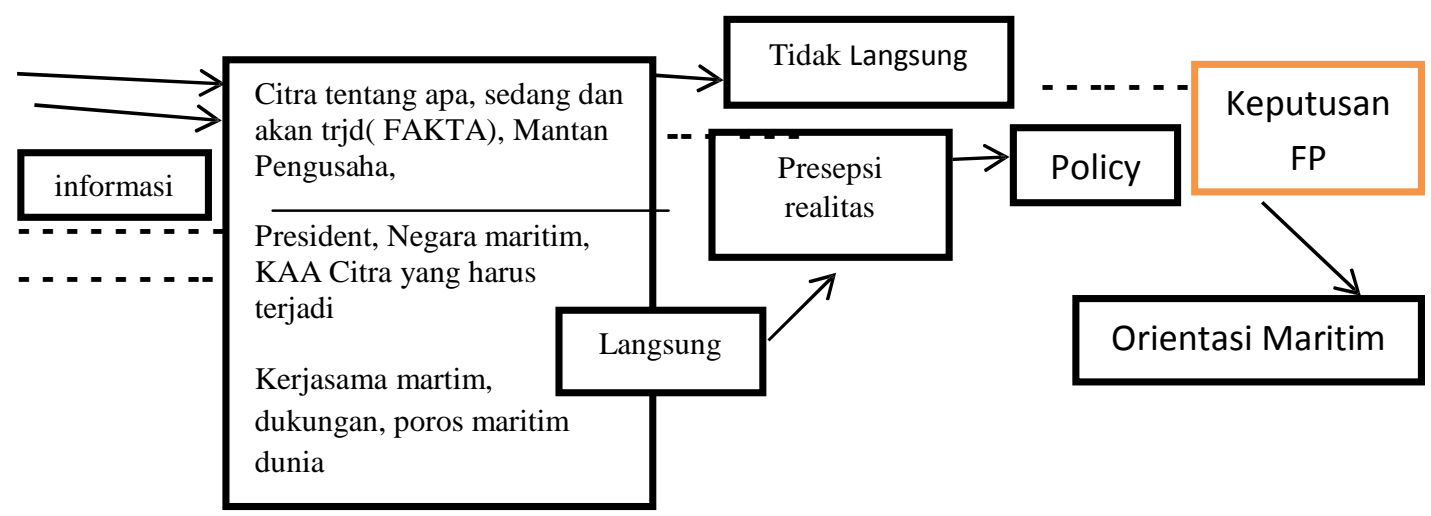

Sumber: Mas'oed $1989: 21$

Skema 3 Psikologi Politik

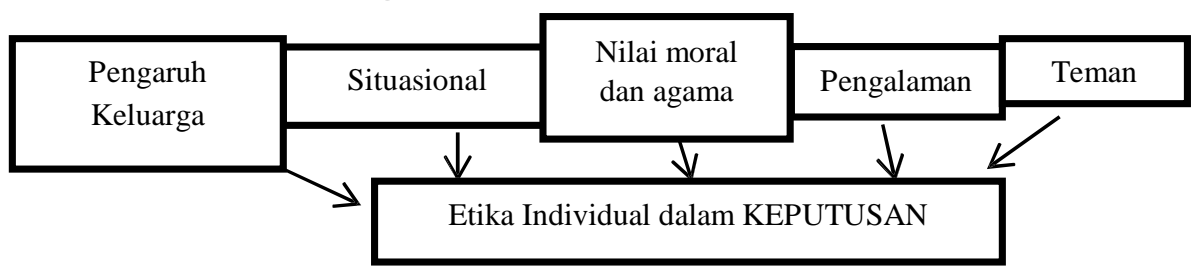

Sumber : Uci Yuliati, 2006:303 


\section{Dinamika Global | Volume 02 | No.02 | Desember 2017}

Teori presepsi Kennet Boulding bahwa manusia terkadang tidak bertindak atas fakta-fakta yang objektif, tetapi manusia bertindak berdasarkan situasi. Artinya presepsi tentang dunia menentukan prilaku (Masoed, 1989:19). Disini menganut asumsi bahwa interpretasi dunia yang salah akibat doktrin akan mempengaruhi psikologis yang serasa berempati tentang dunia yang di konstruksi menjadikannya tidak sesuai apa adanya. Jokowi melalui visinya menjadikan Indonesia sebagai negara maritim terlihat dengan upaya membentuk presepsi peserta konferensi untuk mebentuk citra dan sikap dari sejumlah yang terlibat. Holsti menjelaskan bahwa citra merujuk pada tindakan yang dilakukan oleh pembuat kebijakan berupa gambaran tujuan yang akan di capai dalam situasi tertentu dan tindakan yang akan diambil serta melihat tantangan dari situasi tersebut. Artinya citra menyangkut tentang bagaimana merubah, mempengaruhi tindakan aktor lain terhadap apa yang di gambarkan oleh pengambil kebiakan. Sehingga, berproses pada keyakinan dan sikap yang akan di ambil oleh sejumlah aktor apakah mendukung, membantu atau menolak (Masoed: 86-89).

Bukan tanpa alasan penekanan politik luar negeri berbasis kerjasama maritim kembali di tekankan pada pidato penutupan Konperensi Asia Afrika. Konsep kerjasama maritim menjadi salah satu agenda poin dari inti pidatonya dan dari konten pidato tersebut kontennya adalah pemikiran Jokowi sendiri. "Kita menyadari pentingnya sentralitas sektor maritim serta 


\section{Dinamika Global | Volume 02 | No.02 | Desember 2017}

kepentingan strategis Samudra Hindia, sebagai jembatan pembangunan ekonomi di Asia Afrika. Kerjasama maritim akan menjadi salah satu pilar utama kemitraan strategis baru di Asia Afrika. Saya bekerja dengan anda semua untuk memastikan bahwa kerjasama strategis tersebut akan terwujud" (detik.com).

Dari kutipan pidato tersebut terdeskripsi nyata bahwa politik maritim Indonesia sangat jelas dalam konferensi. Karena menurut Jervis salah satu melihat indikator seorang pengambil kebijakan adalah dari pidatonya. Disambung oleh Holsti bahwa ciri ideosinkretik peran birokrasi sangat kabur, standar operasional tidak terlalu di utamakan. Kebijakan sangat agresif artinya terlihat dominasi dalam sebuah politik internasional terutama dalam marketing politiknya (Holsti,1988:98). Uci Yuliati menekankan pada proses pengambilan keputusan seoramg yaang mengambil teori A maka etika individualnya akan terpengaruh oleh sejulamlah faktor seperti: pengaruh keluarga, situasional, nilai moral dan agama, pengaalamaan, dan pengatuh teman (Uci Yuliati, 2006: 303). Kebijakan yang lahir dari proses wholistik adalah proses intelektual kognitivisme, psikologis sang decision maker dengan model open image untuk mencari elektabilitas, popularitas. Walaupun terkadang saangat rapuh namun bisa juga bersifat sangat tangguh, terutama yang bersifat primary interest (kedaulatan, hukum, militer, politik, ekonomi), yang dibutuhkan adalah konsistensi dan kalkulasi rasional yang baik. 


\section{Dinamika Global | Volume 02 | No.02 | Desember 2017}

Penutup

Terpilihnya Jokowi sebagai Presiden Indonesia ke 7 memberi warna dalam model kebijakan luar negeri Indonesia. Tranformasi kebijakan luar negeri Indonesia yang melanjutkan kebijakan luar negeri SBY sebelumnya merupakan cara Jokowi dalam merubah citra Indonesia di panggung internasional. Pergeseran model kebijakan luar negeri Indonesia untuk menjadi negara yang berbasis pada sumber daya maritim atau sumber daya laut maka kebijakan ini terlihat sebagai warna baru walaupun sebelumnya Soekarno pernah menginginkan Indonesia untuk menjadi negara bahari. Konteks diksi kata memang sangat berbeda namun dari segi substansi makna cenderung sama yakni menjadi negara yang berdaulat di bidang pangan maritim. Munculnya kebijakan luar negeri Indonesia di masa pemerintahan Jokowi merupakan sebuah tesis baru apabila bisa terimplementasi dalam aksi dilapangan.

Untuk mewujudkan hal tersebut Jokowi gencar mempromosikan Indonesia sebagai negara yang berbasis pada ekonomi maritim dan bertujuan sebagai negara poros maritim di dunia. Kebijakan Jokowi di promosikan sebagai marketing politik untuk menarik minta investasi kerjasama dari sejumlah relasi dalam sejumlah konferensi-konferensi internasional. Dalam setiap pidato Jokowi selalu menyisipkan tujuan Indonesia tersebut sebagai agenda penting Indonesia dalam masa pemerintahanya yakni sebagai negara poros maritim dunia. 


\section{Dinamika Global | Volume 02 | No.02 | Desember 2017}

Demikian pula yang terjadi dalam konperensi Asia Afrika pada tahun 2015. Konfrnsi Asia Afrika yang kebetulan dilaksanakan di Indonesia merupakan prospek yang potensial bagi Jokowi untuk kembali menjadikan isu kerjasama maritim sebagai instrument kebijakan luar negerinya. Dan jelas saja dalam sela sambutan kepala negara Jokowi melontarkan kembali kerjasama maritim sebagai isu penting dalam menyambut konperensi Asia Afrika.

Konteks ini tidak terlepas dari pengaruh latar belakang sejarah bangsa Indonesia sebagai negara yang luas dari segi laut. Pengalaman masa lalu dijadikan tolok ukur untuk membangkitkan kembali semangat nusantara yang telah lama punah dan bukan menjadi prioritas. Realitas ini tidak terlepas pula dari karakter pribadi Jokowi untuk menampilkan sesuatu yang beda dengan president sebelumnya. Fenomena wholistic dalam konteks kebijakan luar negeri Jokowi tergambar jelas ketika menyampaikan pidatonya yang memang sebelumnya sudah tercatat dalam visi dan misi Jokowi JK ketika mendaftar sebagai calon presiden dan wakil presiden. 


\section{Dinamika Global | Volume 02 | No.02 | Desember 2017}

Daftar Pustaka

Abi Hara, Abu Bakar, 2011., Pengantar Analisis Politik Luar Negeri, Dari Realisme Samapi Konstruktivisme, : NUANSA, Bandung.

Banyu Parawita, Anak Agung dan muhamad Yani, Yanyan, 2005, Pengantar Studi Hubungan Internasional, : Remaja Rosdakarya, Bnadung.

Carlesnaes, Walter, DKK., 2013, Handbook Hubungan Internasional, : Nus Media, Bandung.

Couloumbis, Theodore A, Wolfe, James H., 1999, Pengantar Hubungan Internasional, Keadilan Dan Power, : CV Putra A Bardin, Bandung.

Coplin., Wiliam D , 1992, Pengantar Politik Internasional, Terjemahan Marcedes Marbun: Edisi Kedua : Sinar Baru, Bandung

Graham. T , Alison ,. 1971, Essence of Decision :Explaning the Cuban Missile Crisis: Little Brown, Boston.

Hanrieder, Wolfram, 1971., Comparative Foreign Policy, Theoretical Essay, : David Mc. Kay Company,Inc,New York.

Holsti, K,J,.1988., Politik Internasional, Kerangka Untuk Analisis, : Erlangga, Jakarta.

Hudson, V,M.,2008, The History and Evolution of Foreign Policy Analisys . In S. Smith, A. Hadfield \& T. Dunne, (Eds), Foreign Policy : theories, actors, cases, Oxford University Press, Oxford.

Jackson, Robert, Sorenson, Georg., 2014, Pengantar Studi Hubungan Internasional,Teori Dan Pendekatan Edisi Ke V : Pustaka Pelajar, Yogyakarta. 


\section{Dinamika Global | Volume 02 | No.02 | Desember 2017}

Kissinger, Henry. Domestic Structureand Foreign Policy,In Hanrieder ,Wolfram, .1971, Comparative Foreign Policy Theoretical: David Mc KAY Company In. New York

Mas'oed, Mohtar, 1994, Ilmu Hubungan Internasional , Disiplin dan Metodologi: LP3S Jakarta.

, 1989, Studi Hubungan Internasional, Tingkat Anaalisis dan Teorisasi, :Pusat Antar Universitas Studi Sosial ,UGM.

May, Rudy, T. 2003., Studi Strategis, Transformasi Pasca Perang Dingin, : Rafika Aditama, Bandung.

McClelland, Charles,. 1981. Ilmu Hubungan Internasional, Teori dan Sistem, :CV Rajawali, Jakarta.

Mintz, Alex, DeRouen., 2010, Understanding Foreign Policy Decision Making: Cmbridge University Press.

Nasution, Dahlan, 1984., Perang Dan Damai Dalam Politik Internasional: Remadja Karya, Bandung.

Rosenau, James N. 1981. The Study of Political Adaptation: Essays on the Analysis of World Politics.: Nichols Publishing, New York.

New York.

1971, Scientific Study Of Foreign Policy: Free Press, 1974, Comparing Foreign Policy: Theories, Findings, and Methods: Sage Publications, New York.

Yuliati, Uci. 2006. Menajemen Internasional Suatu tinjauan Sumberdaya Manusia,: Universitas Muhamadiyah Malng Press, Malang.

Warsito, Tulus.1998., Teori-Teori Politik Luar Negeri, Relevansi dan Keterbatasannya: BIGRAF Publishing, Yogyakarta. 